\title{
Classic Neutrophil Cytoplasmic Antibody Measurement
}

National Cancer Institute

\section{Source}

National Cancer Institute. Classic Neutrophil Cytoplasmic Antibody Measurement. NCI

Thesaurus. Code C147301.

The determination of the amount of classic neutrophil cytoplasmic antibody present in a sample. 